\title{
Measurements of DNA damage and photoreactivation imply that most viruses in marine surface waters are infective
}

\author{
Steven W. Wilhelm ${ }^{1, *}$, Markus G. Weinbauer ${ }^{2}$, Curtis A. Suttle ${ }^{1, * *}$, Ralph J. Pledger $^{3}$, \\ David L. Mitchell ${ }^{3}$ \\ 'Departments of Earth and Ocean Sciences (Oceanography), Botany and Microbiology, The University of British Columbia, \\ 6270 University Blvd, Vancouver, British Columbia V6T 1Z4, Canada \\ ${ }^{2}$ National Research Centre for Biotechnology, Division Microbiology, Mascheroder Weg 1, D-38124 Braunschweig, Germany \\ ${ }^{3}$ The University of Texas M.D. Anderson Cancer Center, Department of Carcinogenesis, Park Road 1, Smithville, Texas 78957, USA
}

\begin{abstract}
The proportion of viruses in natural marine communities that are potentially infectious was inferred from the relationship between DNA damage and the loss of infectivity in marine viral isolates and measurements of the DNA damage in natural viral communities. Several viral isolates which infect marine Vibrio spp. were exposed to UV-C radiation and the concentration of cyclobutane pyrimidine dimers in the viral DNA was measured with a highly sensitive radioimmunoassay. The loss of infectivity in the UV-exposed isolates was also determined under conditions which either activated or repressed the blue light dependent photolyase enzyme in host cells in order to examine the damagedependent response of this bacterial repair system. In addition, the accumulation of DNA photodamage during the solar day was measured in DNA isolated from natural viral communities collected along a transect in the western Gulf of Mexico. Using the correlation between DNA damage and infectivity for one of the viral isolates, we estimated the proportion of the natural viral community which was infective. The results imply that, due to light-mediated repair of damaged viral DNA by host-cell mechanisms (photoreactivation), greater than $50 \%$ of the viruses in natural communities are infective despite high rates of DNA damage. Furthermore, the accumulation of cyclobutane pyrimidine dimers was highest at the station where the surface mixed layer was shallowest, emphasizing the importance of mixing depth in relation to the accumulation of DNA damage. These experiments demonstrate that physical parameters such as mixing depth are critically interwoven with light penetration in influencing the infectivity of marine viral communities.
\end{abstract}

KEY WORDS: Marine viruses - Pyrimidine dimers UV Photoreactivation

\section{INTRODUCTION}

Viruses are abundant and integral members of marine microbial communities, and may have a significant impact on species composition, nutrient cycling and the exchange of genetic material in aquatic

\footnotetext{
- Present address: National Water Research Institute, Aquatic Ecosystem Conservation Branch, 867 Lakeshore Road, PO Box 5050, Burlington, Ontario L7R 4A6, Canada

- Addressee for correspondence. E-mail: suttle@eos.ubc.ca
}

ecosystems (see reviews by Børsheim 1993, Fuhrman \& Suttle 1993, Bratbak et al. 1994). Studies on the dynamics of viral production have suggested that maintenance of the viral community must involve the rapid production of viral particles to replace those which are lost on a daily basis (Suttle \& Chen 1992, Suttle 1994). However, while our ability to enumerate the abundance of viral particles in aquatic systems has improved tremendously in the last decade (reviewed in Suttle 1997), we are still unable to determine the proportion of the natural viral community that is infective. 
The destruction of viral particles and the reduction in infectivity of viral particles has been critically examined during recent years. The infectivity of viral particles has been demonstrated to be sensitive to solar radiation, with ultraviolet $B$ wavelengths (UV-B: 280 to $320 \mathrm{~nm}$ ) being demonstrated to be the most significant in rendering viral particles noninfective in aquatic environments (Suttle \& Chen 1992, Wommack et al. 1996, Noble \& Fuhrman 1997). Estimates of the lightmediated destruction of viral infectivity using marine viral isolates have suggested that the amount of solar radiation penetrating surface waters can be sufficient to remove all viral infectivity from surface waters daily (Suttle \& Chen 1992, Wilhelm et al. 1996). However, high titers of infective viral particles remain in surface waters (Suttle \& Chan 1994). Moreover, while there is a strong correlation between UV-B flux and the destruction of infectivity of marine viral isolates (Suttle \& Chen 1992, Suttle \& Chan 1994, Noble \& Fuhrman 1997), direct measurements of the impact of UV-B on the infectivity of natural viral communities are not attainable with current techniques.

Solar radiation can have multiple effects on virus particles. The most mutagenic and lethal effects of solar radiation are the formation of DNA photoproducts in the viral genome. The most common DNA photoproducts are cyclobutane pyrimidine dimers (CPDs) and pyrimidine-pyrimidone (6-4) photoproducts [(6-4)PPs], which are both formed by exposure of DNA to UV-B radiation (Friedberg et al. 1995). DNA photoproducts in marine viral communities accumulate during the solar day, and are then removed at night by host-mediated repair processes and dilution through the production of new viral particles (Weinbauer unpubl, results).

Several host-cell-mediated processes are responsible for reversing accumulated DNA damage in viruses. The blue-light-activated photolyase enzyme (384 to $438 \mathrm{~nm}$; Kim \& Sancar 1993) in host cells and the subsequent process of photoreactivation (sensu Dulbecco 1949 , 1950) appear to be one of the most prominent DNA repair systems for viruses in the marine environment (Weinbauer et al. 1997). Since Dulbecco's original observations, photoreactivation has been shown to involve the error-free reversal of pyrimidine dimers by the photolyase enzyme (Kim \& Sancar 1993, Friedberg et al. 1995). Other DNA repair mechanisms (e.g. RecAmediated excision repairj involve the removal and replacement of damaged DNA sequences, and have inherent errors which lead to alterations in the original DNA sequence (Friedberg et al. 1995).

While we have demonstrated in previous studies that photoreactivation is a process which is potentially critical in maintaining the high abundance of infectious viruses in marine surface waters (Weinbauer et al.
1997), information on the in situ level of DNA photoproducts remains limited. Here we have developed a correlation between DNA photoproduct concentrations and infectivity for several marine viral isolates. We have used this correlation to infer the infectivity of the natural viral community in the Gulf of Mexico from measurements of in vivo DNA photoproduct concentration. Although it remains unknown how representative these isolates are of the natural viral community, it is reasonable to assume that photoreactivation of damaged DNA in the natural viral community behaves in much the same way as it does in these marine viral isolates. There is also no a priori reason to reject the notion that relationships between DNA damage and infectivity in these isolates are similar to those in natural viral communities. If so, our results suggest that the proportion of infective viruses in marine surface waters may be much higher than previously thought. We present these results in the context of the physical parameters which may influence the abundance of infectious viral particles in marine systems.

\section{METHODS}

Sampling sites. The RV 'Longhorn' occupied several stations along a transect from the oligotrophic central Gulf of Mexico to mesotrophic coastal waters during July 23 to 31,1996 . The accumulation of CPDs in viral particles due to solar radiation was examined at 3 stations: offshore oligotrophic Stns B96 $\left(26^{\circ} 02^{\prime} \mathrm{N}\right.$, $93^{\circ} 29^{\prime} \mathrm{W}$ ) and $\mathrm{C} 96\left(25^{\circ} 34^{\prime} \mathrm{N}, 92^{\circ} 53^{\prime} \mathrm{W}\right)$, and nearshore mesotrophic Stn E96 (27 $\left.29^{\prime} \mathrm{N}, 96^{\circ} 14^{\prime} \mathrm{W}\right)$.

Irradiance and physical measurements. The attenuation of light in the water column was estimated with a Biospherical PUV -500 profiling radiometer at 305, 320, 340 , and $380 \mathrm{~nm}$ (band widths $=10 \mathrm{~nm}$ ) as well as for photosynthetically active radiation (PAR, 400 to $700 \mathrm{~nm})$. The depth (m) at which $1 \%$ of the surface irradiance remained was determined from multiple casts of the radiometer. Surface PAR (400 to $700 \mathrm{~nm}$ ) was measured every 15 min by integration of $5 \mathrm{~s}$ subsamplings with a Licor Li-1000 datalogger equipped with a cosine collector. Values for surface PAR (mol $\mathrm{m}^{-2}$ ) were determined as the integrated sum of data collected during each day. Pycnocline depths were estimated from mean values of multiple profiles of temperature and salinity obtained using a Sea-Bird CTD (model SBE 9 plus).

Viral isolates and hosts. The bacteriophage PWH3aP1 (subsequently referred to as P1) and the bacterium which it lytically infects (Vibrio natriegens strain PWH3a) were isolated from the coastal Gulf of Mexico (Suttle \& Chen 1992). Phages H40/1 and H85/1 and their hosts were the gift of J. Fuhrman (USC, USA) and 
were originally isolated by Moebus (1980). Bacteriophage nt-1 was obtained from the Félix d'Hérelle Reference Center for Bacterial Viruses (Montreal, Canada) and propagated on its host Vibrio natriegens ATCC 14048. All host bacteria were maintained in ultrafiltered seawater $(30$ psu salinity except for $V$. natriegens ATCC 14048, which was maintained at 15 psu) supplemented with peptone, Casamino acids, yeast extract $(0.05 \% \mathrm{w} / \mathrm{v}$ each) and $0.3 \% \mathrm{v} / \mathrm{v}$ glycerol Axenic bacterial stocks were maintained on agar solidified medium (1.0\%) until transferred to liquid culture for experiments. Clonal bacteriophage isolates were amplified to ca $10^{9}$ plaque forming units (PFU) $\mathrm{ml}^{-1}$ prior to experiments.

Introduction of DNA photoproducts into viral isolates. To introduce reproducible levels of DNA photoproduct into viral isolates, $100 \mathrm{ml}$ of filtered $(0.22 \mu \mathrm{m}$ pore-size, Durapore) culture lysates were placed in the bottom of uncovered Petri plates and exposed to increasing doses of energy in a FB-UVXL-1000 UV crosslinker (Fisher Scientific) equipped with UV-C (254 $\mathrm{nm}$ ) bulbs. Samples within the crosslinker were maintained at room temperate and at the same distance from the lamps as the internal sensor. The crosslinker has a built-in UV sensor (Spectronics, accurate $\pm 5 \%$ according to manufacturer's specifications) which integrates the exposure received and compensates for any decline in the intensity of the lamps by increasing the time of exposure. Aliquots $(100 \mu \mathrm{l})$ of samples exposed to a range of UV doses $(0$ to $1000 \mathrm{~J}$ $\mathrm{m}^{-2}$ ) were titred for infectivity by standard plaque assay (Suttle \& Chen 1992) and the remaining sample analyzed to determine the concentration of DNA photoproducts (see below)

It is important to note that an artificial UV-C source was used to damage the DNA of the viral isolates. Since UV-C does not reach the sea surface (Smith \& Baker 1979), the DNA-damage data cannot be used to estimate the amount of solar radiation received by the natural viral community, nor was that our intent. The purpose of using UV-C was to rapidly and reproducibly introduce DNA damage to the viral isolates in order to develop the relationship between DNA damage and loss of infectivity.

To quantify the efficiency of photorepair, the amount of energy required to reduce viral infectivity to $1 \%$ was determined from linear regressions of infectivity versus UV-C $\left(\mathrm{J} \mathrm{m}^{-2}\right)$. The difference in energy required to reduce infectivity to $1 \%$ of the undamaged values for both photoreactivating and non-photoreactivating conditions $\left(\Delta D_{254} \mathrm{~nm}\right)$ was determined from the derived equations (Friedberg et al. 1995). Energy was converted to photon hits virus ${ }^{-1}$ by assuming $7.83 \times 10^{-19} \mathrm{~J}$ photon $^{-1}(254 \mathrm{~nm})$ and a viral capsid cross-sectional area of $60 \times 60 \mathrm{~nm}$.
Collection of natural viral communities. For the determination of in vivo photodamage in the DNA of natural viral communities, $200 \mathrm{l}$ samples of seawater were collected between 03:00 and 18:00 h from the sea surface. Samples were serially filtered through $1.2 \mu \mathrm{m}$ nominal pore-size glass fiber filters (147 mm; MFS GC50) and a $0.2 \mu \mathrm{m}$ pore-size polycarbonate cartridge filter (Nuclepore) to remove zooplankton, phytoplankton and bacteria. The viruses remaining in the $0.2 \mu \mathrm{m}$ filtrate were concentrated ca 1000-fold using ultrafiltration (Suttle et al. 1991) (Amicon S10Y30 and S1Y30 cartridges; $30000 \mathrm{MW}$ cutoff).

Purification of viral DNA and the determination of photoproduct concentrations. For the extraction of DNA, viruses in both pure culture lysates and seawater concentrates were collected by centrifugation $(3 \mathrm{~h}$ at $104000 \times g)$. Viruses were resuspended in $1 \mathrm{ml}$ sterile, ultrafiltered seawater and treated with DNase $(200$ Kunitz units, $2 \mathrm{~h}$ at $37^{\circ} \mathrm{C}$ ). After the addition of $10 \mu \mathrm{l}$ of $0.5 \mathrm{M}$ EDTA (pH 8.0) and $10 \mu$ l of SDS (sodium dodecyl sulphate; $10 \% \mathrm{w} / \mathrm{v})$, samples were heat-treated $\left(95^{\circ} \mathrm{C}\right.$, $15 \mathrm{~min}$ ) to release the DNA from the protein capsids. Viral DNA was purified by phenol-chloroform extraction and precipitated with ethanol (Sambrook et al. 1989). DNA was redissolved in autoclaved deionizeddistilled water, and DNA concentrations in subsamples were determined spectrophotometrically.

CPDs were quantified using a competitive radioimmunoassay (RIA) as described by Mitchell (1996). The antiserum for CPDs was raised against salmon testes DNA in $20 \mathrm{mM}$ acetophenone (a triplet sensitizer which promotes the production of CPDs but not 6-4 photoproducts) and irradiated with a UV-B source (Westinghouse FS20, $20 \mathrm{~W}$ ). For the RIA, 2 to $5 \mathrm{mg}$ of heat denatured sample DNA was incubated with 5 to $10 \mathrm{pg}$ of

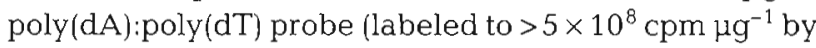
nick translation with ${ }^{32} \mathrm{P}$-dTTP) in a total volume of $1 \mathrm{ml}$ buffer [ $10 \mathrm{mM}$ Tris, $1 \mathrm{mM}$ EDTA, $150 \mathrm{mM} \mathrm{NaCl}, 0.2 \%$ gelatin (Sigma) $\mathrm{pH} 7.8$ ]. Antiserum was added to the reaction mixture at a dilution which yields 30 to $60 \%$ binding of the labeled ligand. After incubation for $3 \mathrm{~h}$ at $37^{\circ} \mathrm{C}$ the immune complex was precipitated with goat anti-rabbit immunoglobulin and a carrier serum from nonimmunized rabbits (both Calbiochem). After centrifugation the supernatant was poured off to waste, the pellet was dissolved in tissue solubilizer (NCS, Amersham), and the entire sample was transferred to a scintillation vial with Scintisafe $30 \%$ LCS cocktail and counted in a Packard 1600TR scintillation counter. DNA photoproducts in the sample DNA are determined by the reduction in counts appearing in the pellet as a result of competition for antibody between the sample DNA and radiolabeled poly $(\mathrm{dA}):$ poly $(\mathrm{dT})$ probe. Each assay was standardized with DNA with known photoproduct content. Samples were analyzed in duplicate. 
Table 1. Physical characteristics of stations in the Gulf of Mexico. Mixing depths $( \pm \mathrm{SD})$ were determined from multiple salinity and temperature profiles

\begin{tabular}{|lcccc|}
\hline Stn & 1\% light penetration depth (m) at & Total surface \\
& 305 $\mathrm{nm}$ & $380 \mathrm{~nm}$ & $\begin{array}{c}\text { Mixing } \\
\text { PAR }\left(\mathrm{J} \mathrm{d}^{-1}\right)\end{array}$ & depth (m) \\
\hline B96 (24 July 1996) & 26.2 & 128.0 & 50.2 & $35.9(2.0)$ \\
C96 (26 July 1996) & 27.4 & 121.2 & 49.6 & $35.2(1.6)$ \\
E96 (29 July 1996) & 25.2 & 98.0 & 52.1 & $18.2(2.5)$ \\
\hline
\end{tabular}

repair systems provided for different titers of infective viruses.

There was a log-linear relationship between the level of infectivity and the concentration of DNA photoproduct for each of the viral isolates. For example, the decrease in infectivity of PWH3a-P1with respect to CPDs was described by:

\section{RESULTS}

\section{Station characteristics}

All stations received similar levels of PAR (Table 1) during the days they were occupied. This, combined with a uniformity in water clarity, provided for similar penetration of UV-B radiation into the water column ( $1 \%$ remaining $305 \mathrm{~nm}$ irradiance at ca 25 to $27 \mathrm{~m}$ ). As predicted, $380 \mathrm{~nm}$ wavelengths penetrated much deeper into the water column $11 \%$ remaining irradiance at ca 98 to $128 \mathrm{~m}$ ) than the shorter wavelengths. The mixed depths were ca $36 \mathrm{~m}$ for the 2 offshore stations, but only ca $18 \mathrm{~m}$ for the nearshore station (E96).

\section{Photodamage and decreases in the infectivity of marine viral isolates}

The infectivity of the viral isolates decreased with increasing exposure to UV-C radiation (Fig. 1). The H40 and $\mathrm{H} 85$ host-virus systems were most tolerant to UV-C exposure, with ca $100 \mathrm{~J} \mathrm{~m}^{-2}$ being required to reduce viral infectivity to $1 \%$ of the undamaged level in the absence of photoreactivating wavelengths (Table 2). Both Vibrio natriegens host-virus systems were significantly more sensitive to UV damage, with only ca $12 \mathrm{~J} \mathrm{~m}^{-2}$ UV-C reducing infectivity to $1 \%$ of the undamaged controls. When the viruses were titred under photoreactivating conditions, the amount of UV-C required to reduce infectivity to $1 \%$ of the undamaged level was even higher. Under photoreactivating conditions, both the $\mathrm{H} 40$ and $\mathrm{H} 85$ host-virus systems required over 300 more $\mathrm{J} \mathrm{m} \mathrm{m}^{-2} \mathrm{UV}-\mathrm{C}\left(\Delta \mathrm{D}_{254 \mathrm{~nm}}\right)$ relative to the nonphotoreactivated samples (Table 2). For both $V$. natriegens host-virus systems, $\Delta \mathrm{D}_{254} \mathrm{~nm}$ values of 115 and $54 \mathrm{~J} \mathrm{~m}^{-2}$ suggest that the hosts of both these systems also have active photoreactivating enzymes.

The accumulation of CPDs in viral isolates PWH3aP1, H40 and H85 demonstrates that photoreactivation restored infectivity to viruses which had received a significant amount of UV-C radiation (Fig. 2). While photoproducts accumulated to similar levels in each of these viruses when exposed to UV-C doses (Table 3), differences in the efficiency of the host-virus DNA $\log (\% \mathrm{PFU})=1.92-\left(3.026 \times 10^{-3}\right.$ [dimers $\left.]\right), \mathrm{r}^{2}=0.970$

In contrast the relationship between the concentration of pyrimidine dimers in P1 and infectivity in the photorepaired samples was second order:

$$
\begin{aligned}
\log (\% \mathrm{PFU}) & =2.02-\left(5.28 \times 10^{-7}[\text { dimers }]^{2}\right) \\
& -\left(7.37 \times 10^{-4}[\text { dimers }]\right), \mathrm{r}^{2}=0.984
\end{aligned}
$$

\section{Accumulation of photodamage in the natural marine viral community}

Cyclobutane pyrimidine dimers accumulated at all stations during the solar day (Fig. 3). Dimer concentrations were low in the morning at offshore Stns B96 and C96 [ca 10 dimers (Mb DNA) ${ }^{-1}$ ] and increased during the solar day to ca 120 and 400 dimers (Mb DNA) ${ }^{-1}$, respectively. CPDs at nearshore Stn E96 were higher

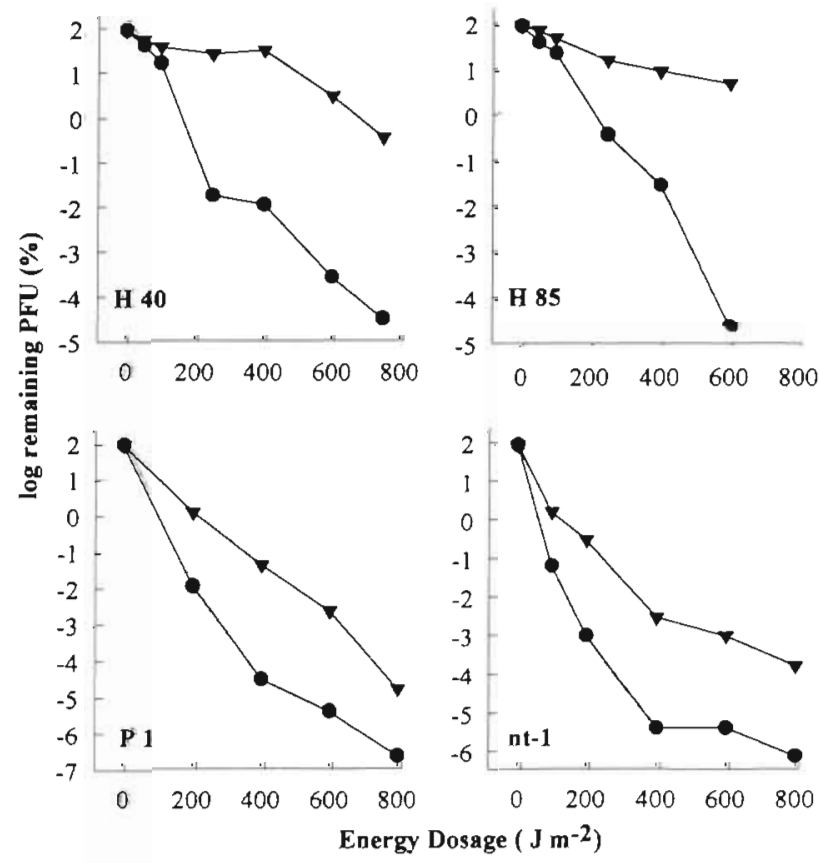

Fig. 1. Infectivity remaining $(n=2$, range is less than symbol size) in viral isolates H40, H85, PWH3a-P1 (P1) and nt-1 after treatment with increasing doses of UV-C radiation. Data are only presented for treatments where infectivity could be detected in both photoreactivating and non-photoreactivating treatments. PFU: plaque forming units 
Table 2. Photorepair efficiency of different marine host-virus systems. The amount of energy ( $\left.\mathrm{J} \mathrm{m}^{-2}, 254 \mathrm{~nm}\right)$ determined to reduce the infectivity of a viral lysate to $1 \%$ of the undamaged level was determined for virus titred under photoreactivating and non-photoreactivating (dark) conditions. Differences between treatments $\left(\Delta \mathrm{D}_{254 \mathrm{~mm}}\right)$ reflect the increased amount of UV-C required to reduce the viral lysates to the same level of infectivity under photoreactivating conditions. Results are also presented in terms of the number of photon hits per virus, assuming a $60 \times 60 \mathrm{~nm}$ cross-sectional area for each of the viral capsids

\begin{tabular}{|c|c|c|c|c|c|c|}
\hline \multirow[t]{2}{*}{ Virus strain } & \multicolumn{2}{|c|}{ Photorepaired } & \multicolumn{2}{|c|}{ Dark conditions } & \multicolumn{2}{|c|}{$\Delta D_{254 \text { nm }}$ values } \\
\hline & $\begin{array}{l}\text { Energy } \\
\left(\mathrm{J} \mathrm{m}^{-2}\right)\end{array}$ & $\begin{array}{l}\text { Photons } \\
(254 \mathrm{~nm})\end{array}$ & $\begin{array}{l}\text { Energy } \\
\left(\mathrm{J} \mathrm{m}^{-2}\right)\end{array}$ & $\begin{array}{l}\text { Photons } \\
\text { (254 nm) }\end{array}$ & $\begin{array}{l}\text { Energy } \\
\left(\mathrm{J} \mathrm{m}^{-2}\right)\end{array}$ & $\begin{array}{l}\text { Photons } \\
\text { (254 nm) }\end{array}$ \\
\hline $\mathrm{H} 40$ & 392 & $1.8 \times 10^{6}$ & 87 & $4.0 \times 10^{5}$ & 305 & $1.4 \times 10^{6}$ \\
\hline H85 & 430 & $2.0 \times 10^{6}$ & 119 & $5.5 \times 10^{5}$ & 311 & $1.4 \times 10^{6}$ \\
\hline $\mathrm{PWH} 3 \mathrm{aP} 1$ & 117 & $5.4 \times 10^{5}$ & 12 & $5.5 \times 10^{4}$ & 105 & $5.3 \times 10^{5}$ \\
\hline Vibrio natriegens nt-1 & 66.4 & $3.1 \times 10^{5}$ & 12.6 & $5.8 \times 10^{4}$ & 53.8 & $2.5 \times 10^{5}$ \\
\hline
\end{tabular}

in the morning, with concentrations peaking much earlier in the day (ca 12:00 h) relative to other stations. Concurrent measurements of another form of DNA damage, (6-4) PP, demonstrated similar patterns of accumulation and removal (data not shown).

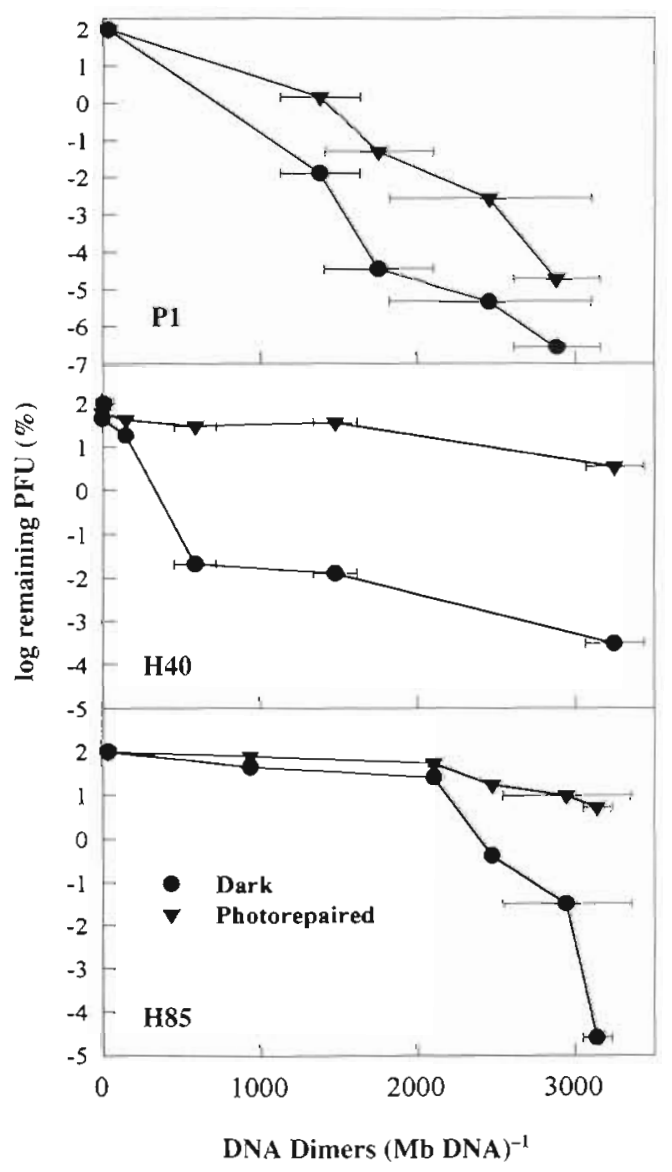

Fig. 2. Relationship between CPD (cyclobutane pyrimidine dimer) formation and infectivity of marine viral isolates titred under photoreactivating and non-photoreactivating conditions. Results (range) for infectivity are presented as a percent of the undamaged treatments, and are the means of duplicates. PFU: plaque forming units

\section{DISCUSSION}

In recent years, the effect of solar radiation on virus infectivity has been viewed as a paradox (Suttle et al. 1993); while high levels of solar-radiation-mediated decay were inferred from viral isolates deployed in situ in the water column, high abundances of infectious viruses remained detectable. The results of this investigation are significant as they suggest that a large percentage of viral particles in natural communities are infectious. Our approach also allows us to compare the potential impact of the photoreactivation of damaged viral DNA with conditions which are non-photoreactivating. Moreover, data were collected from several locations in the Gulf of Mexico, allowing a comparison among stations in terms of physical parameters which may affect the amount of DNA damage.

\section{Differences in the susceptibility of viral isolates to DNA damage}

Although CPDs accumulated in a UV-C dosedependent manner in the different viral isolates, the rates at which infectivity was lost relative to the accumulation of DNA damage differed. The host-virus systems isolated offshore ( $\mathrm{H} 40$ and $\mathrm{H} 85$ ) demonstrated the greatest ability to restore infectivity to damaged viruses under photoreactivating conditions. The different sensitivities of the viruses to UV-C may also be due

Table 3. Accumulation of cyclobutane pyrimidine dimers in marine viral isolates. The concentration of cyclobutane pyrimidine dimers ( $M b$ DNA) ${ }^{-1}$ ( \pm range, $n=2$ ) is given for undamaged control samples and for lysates treated with the maximum amount of $254 \mathrm{~nm}$ light in these experiments $\left(1000 \mathrm{~J} \mathrm{~m}^{-2}\right)$

\begin{tabular}{|lrcr|}
\hline Treatment & PWH3a-P1 & H40 & \multicolumn{1}{c}{ H85 } \\
\hline Undamaged controls & $34(17)$ & $15(9)$ & $41(14)$ \\
$1000 \mathrm{~J} \mathrm{~m}^{-2}$ & $3361(12)$ & $3255(181)$ & $3147(87)$ \\
\hline
\end{tabular}




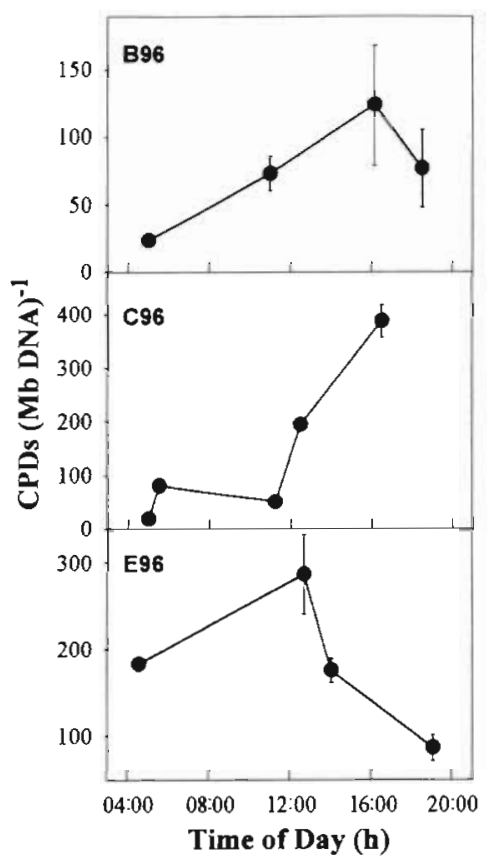

Fig. 3. Accumulation of CPDs (cyclobutane pyrimidine dimers) in the natural viral community. Samples were taken at Stns B96, C96 and E96 in the Gulf of Mexico and the concentration of CPDs in the DNA determined by radioimmunoassay

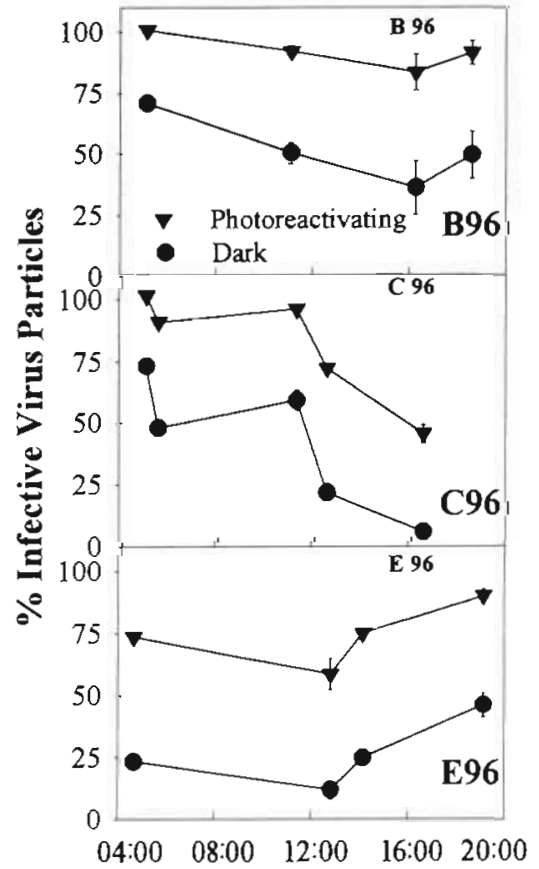

Fig. 4. Inferred infectivity of the natural marine viral communities. The proportion of the natural marine viral community which was infective was estimated from measurements of $\mathrm{CPD}$ accumulation in the natural viral community. These results are from the correlation between $C P D$ formation and infectivity for bacteriophage PWH3a-P1 and are presented for both photoreactivating and non-photoreactivating conditions in part to differences in resistance to solar-radiationmediated DNA damage (other than CPD formation), although this cannot be ascertained from our results. The substitution of standard nucleic acids by unusual bases has been shown in a variety of bacterial viruses (Kreuzer 1988), which may decrease the sensitivity of DNA to solar radiation (Friedberg et al. 1995). Previous studies have demonstrated that the infectivity of different viruses, exposed to the same dose of solar radiation, decays at different rates (Suttle \& Chen 1992, Wommack et al. 1996, Noble \& Fuhrman 1997). However, our results clearly show differential dose responses under photoreactivating and non-photoreactivating conditions. Hence, regardless of any inherent differences among viruses in their susceptibility to CPD formation, the results of these experiments demonstrate that the photorepair mechanisms of all the hosts tested were able to restore infectivity to a significant percentage of the viruses. Moreover, these results show that for the 4 Vibrio spp. studied, differences in the host-cell photorepair abilities affect the maintenance of host-virus systems in high UV environments, and may incorrectly lead to perceived differences in the susceptibility of the viruses to damage from solar radiation.

\section{Infectivity of the natural marine viral community}

The infectivity of the natural viral community was inferred from the relationship between infectivity and DNA photoproduct concentration in bacteriophage PWH3a-P1. This virus exhibits UV-mediated decay rates of infectivity similar to those of other viral isolates from the Gulf of Mexico (Suttle \& Chen 1992, Suttle 1994, Suttle \& Chan 1994). Furthermore, based on restriction fragment polymorphism analysis of multiple viral isolates, the virus has been determined to be common and abundant in the Gulf of Mexico (Wilhelm unpubl results). This host-virus system was also the least efficient of the 3 systems at restoring infectivity by photoreactivation. Thus, PWH3a-P1 likely provides a conservative estimate of the proportion of the natural virus community which may be infective, as use of a correlation between DNA damage and infectivity (Table 2) for either of the offshore host-virus systems $\mathrm{H} 40$ and $\mathrm{H} 85$ yields higher estimates of infectivity.

Estimates of the proportion of the natural viral community in which infectivity can be restored by photoreactivation was found to be surprisingly high at all 3 stations (Fig. 4). At Stn B96, viral infectivity should remain above $80 \%$ for the entire solar day, assuming that photoreactivation was occurring and that contacts between viruses and suitable hosts were not limiting. Even if photoreactivation was not occurring, 
ca $40 \%$ of the viruses should remain infectious on the basis of the DNA damage measured in the natural community. The proportion of infective viruses estimated for Stn C96 was also high under photoreactivating conditions, dropping to only $50 \%$ of the predawn values by the end of the solar day. In contrast, at Stn E96 only ca $75 \%$ of the natural viral community (ca $25 \%$ under non-photoreactivating conditions) appeared to be infective prior to sunrise given the higher level of DNA damage observed. The difference among stations is likely caused by differences in mixing depths (see below).

\section{Ecological implications}

The results presented in this paper demonstrate that DNA damage can accumulate in natural viral communities during the solar day. These data are used to infer the proportion of the viral community which may be infectious and the potential impact of photoreactivation in maintaining infectious viruses in marine surface waters. The accuracy of these estimates is not known as they are based on an individual virus-host system which may be more or less effective than natural bacterial communities at restoring infectivity to damaged viruses. Nonetheless the results demonstrate that the infectivity of natural communities is likely much higher than would be predicted from estimates based on in situ decay rates of viral isolates (Suttle \& Chen 1992, Suttle 1994).

The 3 stations occupied during these experiments provided an opportunity to examine the role of mixing in the maintenance of viral abundance. While the stations were of similar transparency $(1 \%$ UV-B levels ca $26 \mathrm{~m}$ ), the mixing depth at Stn E96 was only half that of the other 2 stations. This implies that at Stn E96 all of the viruses above the pycnocline were continuously exposed to UV-B levels greater than $1 \%$ of the surface levels. In contrast only ca $70 \%$ of the natural viral community in the mixed layer at Stns B96 and C96 were exposed to UV-B levels $>1 \%$ of those at the surface. Yet, the entire community was exposed to photoreactivating wavelengths (cf. $380 \mathrm{~nm}$, Table 1). This suggests that, at Stns B96 and C96, the viruses were mixed to depths where photoreactivation could repair CPDs in the absence of continuing damage from UV-B. In contrast, at Stn E96 the entire viral community was exposed to UV-B radiation $>4 \%$ of surface levels. While the theoretical importance of mixing in the maintenance of viral communities in UV-exposed surface waters was debated by Murray \& Jackson (1993), our results support the contention that mixing is important and demonstrate the potential significance of photoreactivation
The results also provide insight into the effectiveness of light-independent processes at removing accumulated CPDs in viral DNA. The high background level of CPDs, ca 200 (Mb DNA) $^{-1}$ prior to sunrise at Stn E96, indicates that not all of the CPDs in the natural viral community were removed during the night, when only light-independent mechanisms would be active. Although 200 dimers ( $\mathrm{Mb} \mathrm{DNA})^{-1}$ is similar to the predawn levels of bacterial CPDs in the Gulf of Mexico (Jeffrey et al. 1996a, b), it is higher than levels determined for viruses at the other stations in this study [ca 10 dimers (Mb DNA $)^{-2}$ ] as well as previous studies [ca 50 dimers $(\mathrm{Mb} D N A)^{-1}$ for $\mathrm{n}=4$ stations; Weinbauer unpubl. results]. It is possible that lower levels of CPD concentrations are 'tolerated' by light-independent repair mechanisms and left to be repaired when conditions allow for photoreactivation (Friedberg et al. 1995).

Modeling the impact of viruses on marine planktonic communities has been complicated by our inability to estimate the proportion of the natural marine viral community which is infective. Assuming that viruses in the natural system behave as our isolates (with respect to the impact of DNA damage on viral infectivity) then the present study implies that the majority of the viral particles in the water column are infective or can be rendered infective even in the presence of high doses of UV-B.

Acknowledgements. We thank the captain and the crew of the RV 'Longhorn' for assistance in collecting water samples and $W$. H. Jeffrey and K. H. Dunton for light data and monitoring equipment. The help of M. G. Booth, A. M. Chan, D. R. Garza, L. Hutchinson and S. M. Short was greatly appreciated. This research was supported by grants from the Office of Naval Research (N00014-92-5-1676), the National Science Foundation (OCE-9415602) and the Natural Sciences and Engineering Research Council of Canada to C.A.S., and a Erwin-Schrödinger Postdoctoral Fellowship (J00991-BIO) to M.G.W. from the Austrian Science Foundation.

\section{LITERATURE CITED}

Børsheim NY (1993) Native marine bacteriophages. FEMS Microbiol Ecol 102:141-159

Bratbak G, Thingstad F, Heldal M (1994) Viruses and the microbial loop. Microb Ecol 28:209-221

Dulbecco R (1949) Reactivation of ultra-violet-inactivated bacteriophage by visible light. Nature 163:949-950

Dulbecco R (1950) Experiments on photoreactivation of bacteriophages inactivated with ultraviolet radiation. $\mathrm{J}$ Bacteriol 59:329-347

Friedberg EC, Walker GC, Siede W (1995) DNA repair and mutagenesis. ASM Press, Washington

Fuhrman JA, Noble RT (1995) Viruses and protists cause similar bacterial mortality in coastal seawater. Limnol Oceanogr 40:1236-1242

Fuhrman JA, Suttle CA (1993) Viruses in marine planktonic systems. Oceanography 6:51-63 
Hennes KP, Suttle CA (1995) Direct counts of viruses in natural waters and laboratory cultures by epifluorescence microscopy. Limnol Oceanogr 40:1050-1055

Jeffrey $W H$, Aas $P$, Lyons $M M$, Coffin RB, Pledger RJ, Mitchell DL (1996a) Ambient solar radiation-induced photodamage in marine bacterioplankton. Photochem Photobiol 64:419-427

Jeffrey $W H$, Pledger RJ, Aas $P$, Hager $S$, Coffin RB, von Haven R, Mitchell DL (1996b) Diel and depth profiles of DNA photodamage in bacterioplankton exposed to ambient solar ultraviolet radiation. Mar Ecol Prog Ser 137 : 283-291

Kim ST, Sancar A (1993) Photochemistry, photophysics, and mechanisms of pyrimidine dimer repair by DNA photolyase. Photochem Photobiol 57:895-904

Kreuzer KN (1988) Bacteriophage. In: Joklik WK (ed) Virology. Appleton and Lange, San Mateo, p 134-149

Mitchell DL (1996) Radioimmunoassay of DNA damaged by ultraviolet light. In: Pfeiffer G (ed) Technologies for DNA damage and mutations. Plenum Publishing Corp, New York, p 73-83

Moebus K (1980) A method for the detection of bacteriophages from ocean water. Helgoländer Meeresunters 34 : $1-14$

Murray AG, Jackson GA (1993) Viral dynamics II: a model of the interaction of ultraviolet light and mixing processes on virus survival in seawater. Mar Ecol Prog Ser 102: $105-114$

Noble RT, Fuhrman JA (1997) Virus decay and its cause in coastal waters. Appl Environ Microbiol 63:77-83

Proctor LM, Fuhrman JA (1990) Viral mortality of marine bacteria and cyanobacteria. Nature 343:60-62

Sambrook J, Fritsch EF, Maniatis T (1989) Molecular cloning. A laboratory manual. Cold Spring Harbor Laboratory Press, Cold Spring Harbor

Smith RC, Baker KS (1979) Penetration of UV-B and biologi-

Editorial responsibility: David Karl,

Honolulu, Hawaii, USA cally effective dose-rates in natural waters. Photochem Photobiol 29:311-323

Suttle CA (1994) The significance of viruses to mortality in aquatic microbial communities. Microb Ecol 28:237-243

Suttle CA (1997) Community structure: viruses. In: Hurst CJ, Knudsen GR, McInerney MJ, Statzenbach JD, Walter MV (eds) Manual of environmental microbiology. ASM Press, Washington, p 272-277

Suttle CA, Chan AM (1994) Dynamics and distribution of cyanophages and their effect on marine Synechococcus spp. Appl Environ Microbiol 60:3167-3174

Suttle CA, Chan AM, Chen F, Garza DR (1993) Cyanophages and sunlight: a paradox. In: Guerrero $\mathrm{R}$, Pedrós-Alió C (eds) Trends in microbial ecology. Spanish Society for Microbiology, Barcelona, p 303-307

Suttle CA, Chan AM, Cottrell MT (1990) Infection of phytoplankton by viruses and reduction of primary productivity. Nature 347:467-469

Suttle CA, Chan AM, Cottrell MT (1991) Use of ultrafiltration to isolate viruses from seawater which are pathogens of marine phytoplankton. Appl Environ Microbiol 57: $721-726$

Suttle CA, Chen F (1992) Mechanisms and rates of decay of marine viruses in seawater. Appl Environ Microbiol 58: 3721-3729

Weinbauer MG, Wilhelm SW, Garza DR, Suttle CA (1997) Light-dependent repair restores infectivity to natural marine viral communities and maintains high concentrations of viruses in the sea. Appl Environ Microbiol 63: 2200-2205

Wilhelm SW, Weinbauer MG, Garza DR, Rodda KM, Jeffrey WH, Suttle CA (1996) Light driven decay and repair of viruses in the Gulf of Mexico. EOS Trans 76(3):OS 208

Wommack KE, Hill RT, Muller TA, Colwell RR (1996) Effects of sunlight on bacteriophage viability and structure. Appl Environ Microbiol 62:1336-1341

Submitted: April 22, 1997; Accepted: September 4, 1997

Proofs received from author(s): March 10, 1998 